\title{
KERAGAMAN GENETIK, KEBUGARAN DAN INKOMPATIBILITAS REPRODUKSI Hemiptarsenus varicornis Girault (Hymenoptera: Eulophidae), PARASITOID LARVA Liriomyza huidobrensis (Diptera: Agromyzidae)
}

\author{
Reflinaldon', Damayanti Buchori² \& Dwinardi Aprianto $^{3}$ \\ ${ }^{1}$ Jurusan Hama dan Penyakit Tumbuhan Fakultas Pertanian Universitas Andalas, Kampus Limau Manis Padang 25163. \\ E-mail: refli_naldon@yahoo.com \\ ${ }^{2}$ Departemen Proteksi Tanaman, Fakultas Pertanian, IPB, Jl. Kamper Kampus Darmaga Bogor 16680 \\ ${ }^{3}$ Jurusan Proteksi Tanaman, Fakultas Pertanian, Universitas Bengkulu, Jl. Raya Kandang Limun Bengkulu 38371. \\ E-mail: dwi_nardi@yahoo.com
}

\begin{abstract}
Genetic variation, fitness and reproductive incompatibility of Hemiptarsenus varicornis Girault (Hymenoptera: Eulophidae), a larval parasitoid of Liriomyza huidobrensis (Diptera: Agromyzidae). Several experiments have been conducted to study genetic variation, fitness and reproductive incompatibility of $H$. varicornis from different geographic populations. Genetic variation from Pandai Sikek (PS), Alahan Panjang (AP) and Kayu Aro (KA) was analyzed by using random amplified polymorphic DNA-polymerase chain reaction (RAPD-PCR) technique and the similarity of genetics measured using NTSys program. The fitness of female wasps such as longevity, fecundity and preoviposition was observed and then compared among those populations. Incompatibility in reproduction was determined by accounting of reproductive compatibility (RC) index in crossing of intra and interpopulation both of PS and AP. The results showed high genetic variation of H. varicornis among population from Alahan Panjang, Pandai Sikek and Kayu Aro with similarity coefficient of 30 to $70 \%$. The best fitness showed the female wasps from Kayu Aro that was significantly different $(\mathrm{P}=0.00)$ in longevity $(24.60 \pm 6.4$ days), fecundity $(63.6 \pm 28.6 \mathrm{eggs})$ and parasitization $(53.60 \%)$ but not significantly different $(\mathrm{P}=0.07)$ in number of the first day eggs (1.1 \pm 1.4 eggs). Crossing of AP and PS indicated incompatibility in reproduction among the population.
\end{abstract}

Key words: fitness traits, genetic variation, Hemiptarsenus varicornis, reproductive incompatibility

\begin{abstract}
ABSTRAK
Keragaman Genetik, Kebugaran dan Inkompatibilitas Reproduksi Hemiptarsenus varicornis Girault (Hymenoptera: Eulophidae), Parasitoid Larva Liriomyza huidobrensis (Diptera: Agromyzidae). Beberapa percobaan telah dilaksanakan untuk mempelajari keragaman genetik, kebugaran dan ketidaksesuaian reproduksi $H$. varicornis dari populasi berbeda secara geografi. Keragaman genetik populasi H. varicornis berasal dari daerah Pandai Sikek (PS), Alahan Panjang (AP) dan Kayu Aro (KA) dianalisis menggunakan metode RAPD-PCR dan penentuan tingkat kesamaan menggunakan program NTSys. Kebugaran imago betina $H$. varicornis ditentukan dengan pengamatan terhadap lama hidup, keperidian dan masa prapeneluran. Sementara, ketidaksesuaian reproduksi hanya diamati pada populasi PS dan AP dengan menghitung indeks kompatibilitas persilangan intra dan interpopulasinya. Hasil menunjukkan bahwa keragaman genetik populasi $H$. varicornis dari AP, PS dan KA tinggi karena indeks kesamaannya hanya berkisar $30-70 \%$. Kebugaran terbaik diperlihatkan oleh $H$. varicornis berasal dari KA yang ditunjukkan oleh perbedaan nyata $(\mathrm{P}=0,00)$ pada lama hidup $(24,60 \pm 6,4$ hari $)$, keperidian $(63,6 \pm 28,6$ butir telur $)$ dan parasitisasi $(53,60 \%)$ tetapi tidak berbeda nyata $(\mathrm{P}=0,07)$ dalam jumlah telur hari pertama $(1,1 \pm 1,4$ butir telur). Persilangan antara populasi AP dan PS mengindikasikan adanya ketidaksesuaian reproduksi (inkompatibel) antara populasi AP dan PS.
\end{abstract}

Kata kunci: keragaman genetik, $H$. varicornis, ketidaksesuaian reproduksi, sifat kebugaran

\section{PENDAHULUAN}

Hemiptarsenus varicornis (Hymenoptera: Eulophidae) merupakan salah satu jenis parasitoid penting hama pengorok daun (Liriomyza spp.) di
Indonesia (Rauf, 2003). Parasitoid ini ditemukan tersebar luas di pertanaman sayuran terutama dataran tinggi di Jawa, Sumatera dan Sulawesi (Rauf \& Shepard, 1999; Sembel et al., 2003). H. varicornis selalu ditemukan dominan di sentra sayuran dataran tinggi. Di 
Jawa parasitoid ditemukan di Garut, Banjarnegara dan Pengalengan (Purnomo et al., 2003; Reflinaldon et al., 2000). Sementara di Sumatera, parasitoid tersebut ditemukan di pertanaman sayuran dataran tinggi Alahan Panjang, Pandai Sikek dan Bukittinggi (Reflinaldon et al., 1999).

Berkenaan dengan penyebaran $H$. varicornis yang cukup luas maka aspek keragaman menjadi faktor penting. Perbedaan lingkungan dapat memengaruhi kemampuan adaptasi dan tanggap parasitoid secara intrinsik sehingga berkontribusi terhadap terbentuknya keragaman intraspesifik (Diehl \& Bush, 1984; Mackenzie et al., 1998). Hambatan geografis dapat pula menyebabkan peningkatan keragaman karena aliran gen (gen flow) melalui perkawinan tidak dapat terjadi secara intens antara satu populasi dengan populasi lainnya (Bordenstein et al., 2000).

Penyelidikan mengenai keragaman intraspesies (intraspecific variation) membantu kita memahami struktur populasi yang terbentuk di lapang. Pendekatan molekuler saat ini banyak dilakukan untuk menelusuri keragaman genetik dalam dan antar populasi (within and between population) yang berbeda secara geografis (Hidayat, 2000; Loxdale et al., 1996; Hoy, 1994). Studi ini membantu mengungkapkan struktur populasi $H$. varicornis yang terdistribusi secara panmitik atau merupakan metapopulasi. Selanjutnya, keragaman genetik $H$. varicornis dapat pula didalami melalui aspek reproduksi yang terkait dengan sifat kebugaran dan keragaan (fitness and performance traits) dan dapat ditelusuri pula dengan kajian kesesuaian reproduksi melalui persilangan antar populasi.

Studi reproductive compatibility parasitoid dilakukan untuk mengatasi permasalahan dalam pengendalian hayati terutama dalam program pelepasan parasitoid. Selama ini, salah satu faktor penyebab kegagalan pengendalian hayati adalah kurangnya informasi tentang adanya ketidaksesuaian reproduksi populasi yang dilepas dengan populasi asli sehingga perkembangannya tidak terjadi (Stouthamer et al., 2000). Pinto et al. (1991) mengamati kejadian tersebut pada parasitoid Trichogramma, dimana sedikitnya jumlah betina yang ditemukan di lapang yang mengindikasikan bahwa telah terjadi ketidakcocokan perkawinan antar strain. Kajian kesesuaian reproduksi bermaksud untuk menjelaskan kemungkinan yang terjadi bila dilakukan persilangan antar populasi parasitoid $H$. varicornis di laboratorium untuk perbanyakan. Begitu pula kemungkinan untuk melakukan pelepasan dimana parasitoid yang berasal dari populasi suatu daerah. Penelitian ini bertujuan untuk mendapatkan tentang keragaman genetik, kebugaran dan kesesuaian reproduksi dari populasi $H$. varicornis berbeda geografi.

\section{METODE PENELITIAN}

\section{Pengumpulan dan pemeliharaan parasitoid.} Pengumpulan serangga parasitoid di daerah Alahan Panjang (AP), Kabupaten Solok (elevasi 1200-1300 m), Pandai Sikek (PS), Kabupaten Tanah Datar (900-1000 m) dan Kayu Aro (KA), Kabupaten Kerinci (1300-1500 m) yang merupakan daerah pertanaman sayuran dengan tingkat elevasi berbeda. Pelaksanaan koleksi di lapangan dan pemeliharaan di Laboratorium PHT Jurusan Hama dan Penyakit Tumbuhan, Universitas Andalas dilakukan pada bulan Maret sampai Desember 2004.

Sampling dilakukan secara purposive pada setiap lahan pertanaman yang dipilih. Pada masing-masing daerah dipilih 2 areal pertanaman terpisah sehingga ada 6 populasi yaitu AP1, AP2, PS1, PS2, KA1 dan KA2. Populasi parasitoid yang dikoleksi dari AP dan KA berasal dari tanaman kentang sedangkan PS berasal dari tanaman buncis. Koleksi dilakukan dengan cara mengumpulkan daun-daun terserang berupa korokan dari larva hama pengorok daun.

Daun-daun yang telah dikoleksi dari lapang ditempatkan dalam wadah pemeliharaan berupa plastik berbentuk silinder (tinggi $20 \mathrm{~cm}$, diameter $15 \mathrm{~cm}$ ) dengan ditutupi kasa (kain jenis til) dalam ruangan dengan temperatur $23^{\circ} \mathrm{C}$ di laboratorium. Parasitoid yang berasal dari lokasi dan tanaman tertentu dipelihara secara terpisah satu dengan lainnya sebagai populasipopulasi yang berlainan. Semua wadah pemeliharaan disusun di atas rak dengan label lokasi, tanggal koleksi dan tanaman inang. Selanjutnya, setiap hari dilakukan pengamatan munculnya parasitoid. Parasitoid yang muncul tersebut selanjutnya disimpan dalam botol koleksi berisi alkohol 90\% dengan diberi label lokasi dan tanaman inang asalnya sebagai bahan dalam pengujian analisis DNA.

Pengujian Keragaman Genetik. Analisis DNA dilakukan dengan teknik RAPD-PCR di Laboratorium Balai Penelitian Bioteknologi, Cimanggu Bogor. Tahapan pelaksanaan sebagai berikut: ekstraksi DNA parasitoid ini menggunakan metode Meilin (1999) yang telah dimodifikasi. Sebanyak 3 ekor serangga parasitoid dari masing-masing sampel dimasukkan ke dalam tabung eppendorf $1,5 \mathrm{ml}$. Kemudian ditambahkan $400 \mu \mathrm{l}$ buffer TEN (Tris 10 mM EDTA $2 \mathrm{mM}$, dan $\mathrm{NaCl}$ 0,4 M) sedikit demi sedikit sambil digerus, selanjutnya ditambahkan 
$40 \mu \mathrm{l}$ SDS 20\% (w/v) dan $8 \mu \mathrm{l}$ Proteinase K $20 \mathrm{mg}$ $\mathrm{ml}^{-1}$ sambil diaduk-aduk. Sel yang telah diekstrak diinkubasi dalam penangas air dengan suhu $55^{\circ} \mathrm{C}$ selama lebih kurang 1 jam. Setelah itu ditambahkan $300 \mu \mathrm{l} \mathrm{NaCl}$ $5 \mathrm{M}$ dan divorteks (dicampur merata) secara cepat dan disentrifugasi selama 15 menit dengan kecepatan 12.000 g pada suhu $4^{\circ} \mathrm{C}$.

Pada tahapan berikutnya cairan pada bagian atas tabung (supernatan) dipindahkan ke dalam tabung eppendorf yang baru. Kemudian DNA yang berada pada supernatan diendapkan dengan menambahkan isopropanol sebanyak $1 \mathrm{X}$ (volume/volume) supernatan dan disimpan di freezer $-20^{\circ} \mathrm{C}$ selama 30 menit atau untuk hasil yang lebih baik dapat disimpan selama satu malam (overnight). DNA yang sudah mengendap (menggumpal) dipisahkan dari cairan tadi dengan cara mensentrifugasi tabung selama 15 menit pada kecepatan $12.000 \mathrm{rpm}$ suhu $4^{\circ} \mathrm{C}$. Buang cairan dan pelet DNA yang diperoleh dicuci dengan ETOH 70\%, langsung keringanginkan. Pada tahap akhir pelet DNA dilarutkan dalam $30 \mu \mathrm{l}$ buffer TE (tergantung besar kecilnya pellet). DNA yang sudah dilarutkan dijadikan templat atau cetakan dalam analisis PCR. Biasanya DNA yang digunakan disamakan konsentrasinya untuk setiap sampel (10 ng $\left.\mu \mathrm{l}^{-1}\right)$.

Pada tahapan analisis PCR, dilakukan melalui prosedur pembuatan total reaksi sebanyak 201 yang mengandung 10 ng DNA genomik cetakan, masingmasing dNTP $0.1 \mu \mathrm{M}$ (dATP, dCTP, dGTP, dan dTTP), masing-masing primer (OPN-16, OPA-02, OPG-18, DAN OPJ-04) 0.5 pmol, enzim Taq DNA polymerase 1 unit dalam larutan buffer PCR $1 X$. Urutan basa dari primer tersebut adalah: OPN-16 (5'-AAGCGACCTG3'), OPA-02 (5'-TGCCGAGCTG-3'), OPG-18 (5' GGCTCATGTG-3'), dan OPJ-04 (5'-ACGGCAGCTG3'). Reaksi PCR dilakukan pada volume $20 \mu \mathrm{l}$ menggunakan mesin PCR MJ Research PCT-100.

Program PCR terdiri dari pre-denaturasi pada suhu $94^{\circ} \mathrm{C}$, selama 2 menit, dilanjutkan dengan 45 siklus yang terdiri dari denaturasi pada suhu $94^{\circ} \mathrm{C}, 1$ menit, annealing pada suhu $36^{\circ} \mathrm{C}$, menit, dan extension $72^{\circ} \mathrm{C}$, 2 menit. Pada tahap terakhir proses PCR dilakukan final extension pada suhu $72^{\circ} \mathrm{C}$ selama 5 menit. Sebanyak $10 \mu \mathrm{l}$ produk PCR hasil amplifikasi dianalisis dengan elektroforesis pada gel agarose 1,2\% (w/v).

Tiap pita DNA yang muncul dari hasil reaksi RAPD-PCR dianggap sebagai satu lokus tersendiri dan dikelompokkan sesuai berat molekulnya kemudian diskor secara visual keberadaannya, yaitu 1 untuk pita yang terbentuk dan 0 jika tidak ada pita.
Analisis data. Data pengamatan dianalisis kekerabatan genetiknya menggunakan program SAHN dari NTSYSpc 2.1. Berdasarkan nilai kesamaan genetika tersebut dilakukan analisis pengelompokan (cluster analysis) menggunakan metode UPGMA yang menghasilkan dendogram kesamaan genetika.

\section{Studi Kebugaran Parasitoid dari Geografi Berbeda.} Pengamatan lama hidup, keperidian, produksi telur perhari. Parasitoid berasal dari Pandai Sikek, Alahan Panjang dan Kayu Aro (paternal population) sedangkan inangnya diambil dari biakan hama pengorok yang telah dipelihara pada tanaman kacang merah di rumah kawat. Sepasang imago parasitoid yang baru muncul dari setiap pelakuan ditempatkan dalam wadah plastik berbentuk gelas (diameter alas $5 \mathrm{~cm}$, atas $8 \mathrm{~cm}$ dan tinggi $14 \mathrm{~cm}$ ). Segera setelah itu, ke dalam wadah tersebut dipaparkan tiga larva inang yang berada dalam korokan daun. Untuk menjaga kesegarannya, daun-daun tersebut diberi kapas lembab yang dibalutkan pada tangkainya. Setiap 24 jam, larva yang dipaparkan diganti dengan yang baru. Dari larva inang yang telah dipaparkan tersebut selanjutnya dihitung jumlah telur yang diletakkan oleh parasitoid yaitu dengan cara membedah gejala korokan pada daun di bawah mikroskop binokuler. Penggantian larva dilakukan terus menerus sampai imago betina parasitoid tersebut mati. Dari percobaan ini diperoleh data keperidian total, produksi telur per hari dan lama hidup betina. Dalam percobaan ini, jumlah betina yang diujikan sebanyak 20 ekor. Seluruh percobaan di atas dilaksanakan dalam ruangan bertemperatur $23^{\circ} \mathrm{C}$.

Parasitisasi dan superparasitisasi. Pengamatan parasitisasi dan superparasitisasi sejalan dengan pengamatan jumlah telur dan lama hidup betina di atas. Parasitisasi berdasarkan pada asumsi peletakkan telur oleh parasitoid pada atau di dekat larva inang. Parasitisasi dihitung berdasarkan persentase perbandingan jumlah inang yang diletakkan telur dengan total jumlah inang yang dipaparkan. Superparasitisasi merupakan kejadian parasisitisasi dengan asumsi bila peletakan lebih dari satu telur pada setiap larva inang. Pengamatan dilakukan setiap 24 jam selama masa hidup betina.

Masa praoviposisi. Pengamatan masa praoviposisi dilakukan terpisah dengan pengamatan di atas. Seekor betina yang baru saja muncul dari pupa segera dipaparkan larva inang. Setiap 2 jam larva inang diganti dan larva yang telah dipaparkan tersebut diamati di bawah 
mikroskop untuk mengetahui ada tidaknya telur yang diletakkan. Masa oviposisi adalah lama waktu yang dilalui oleh betina sampai peletakkan telur pertamanya. Percobaan dilakukan dengan ulangan sebanyak 10 kali setiap perlakuan.

Analisis data. Data lama hidup, jumlah telur, telur hari I, parasitisasi dan superparasitisasi dianalisis menggunakan Program Statistik versi 8.0 dengan pengujian nilai tengah menggunakan uji Tukey pada taraf 5\% dan disajikan dalam bentuk tabel. Masa praoviposisi betina dari masing-masing daerah dibandingkan dalam bentuk grafik.

\section{Pengujian kompatibilitas reproduksi dari populasi}

berbeda daerah. Serangga uji berasal dari biakan beberapa populasi parasitoid di laboratorium yang dikoleksi dari berbagai lokasi dari Alahan Panjang (AP) dan Pandai Sikek (PS). Di laboratorium setiap populasi dipelihara secara terpisah untuk mendapatkan betina murni dari setiap populasi (isofemale line) sehingga betina dan jantan yang baru muncul segera dipisahkan untuk menghindari perkawinan sebelum diperlakukan. Selanjutnya, betina dari setiap populasi dikawinkan dengan jantan dari populasi lainnya sebagai perlakuan sedangkan untuk kontrol dilakukan juga perkawinan antara jantan betina dalam satu populasi. Kombinasi perkawinan disajikan dalam bentuk matriks berikut:

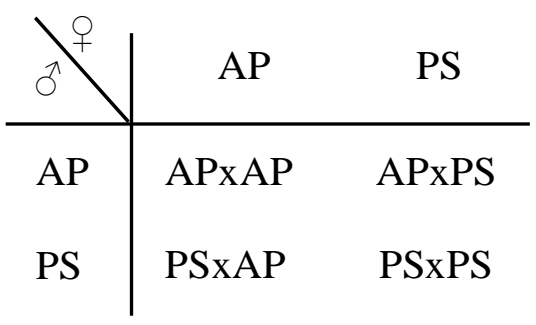

Dari perkawinan baik di dalam dan antar populasi maka akan ada 4 kombinasi (perlakuan) dengan ulangan sebanyak 20 kali untuk perkawinan intrapopulasi dan 10 kali untuk perkawinan interpopulasi. Betina yang telah dikawinkan selanjutnya akan dipelihara dengan cara memaparkan larva inang hama pengorok yang diganti setiap hari (24 jam) dengan larva inang baru. Larva yang telah dipaparkan tersebut kemudian akan ditempatkan dalam cawan Petri untuk menunggu sampai semua anak (turunan) yang dihasilkan muncul menjadi imago. Hal ini dilakukan karena dalam penentuan kelamin lebih mudah pada stadium imago dengan berdasarkan perbedaan bentuk antene. Semua anak yang dihasilkan dari setiap perlakuan dihitung nisbah kelamin (sex ratio) yaitu perbandingan antara jantan dan betina. Dari nilai rataan nisbah kelamin (mean sex ratio $=$ MSR) dari setiap perkawinan tersebut, kemudian ditentukan pula nilai ratio compatibility (RC) berdasarkan metode yang digunakan Pinto et al. (1991) yang didefinisikan sebagai perbandingan proporsi anak betina dari perkawinan inter populasi dengan proporsi anak betina dari perkawinan intra populasi. Parameter biologi reproduksi meliputi lama hidup betina dan jumlah telur diamati pula untuk mengetahui pengaruh dari perkawinan persilangan. Data dianalisis menggunakan program Statistik 8.0.

\section{HASIL DAN PEMBAHASAN}

\section{Keragaman genetik H.varicornis dari populasi} berbeda geografi. Profil pita RAPD yang dapat diamplifikasi dari keenam populasi $H$. varicornis diperlihatkan pada Gambar 1. Dari empat primer yang digunakan hanya dua primer OPJ-04 dan OPN-16 yang dapat mengamplifikasi keenam populasi yang diuji. Jumlah pita yang dihasilkan adalah berkisar antara 4 (OPJ-04) sampai dengan 8 (OPN-16). Dendogram hasil analisis program NTSys enam populasi parasitoid berdasarkan kemiripan genetik dikonstruksi berdasarkan UPGMA dengan menggunakan koefisien Jaccard pada 4 lokus RAPD disajikan pada Gambar 2.

Dari pengelompokan enam populasi parasitoid berdasarkan uji kesamaan diperoleh dua kelompok utama pada tingkat kesamaan 34\%. Populasi yang termasuk kelompok pertama adalah KA1, AP1, PS2, KA2 dan AP2. Sedangkan kelompok kedua hanya ditempati oleh populasi PS1. Populasi AP2 mengelompok dengan populasi KA1, AP1, PS2 dan KA2 pada tingkat kesamaan $55 \%$.

Pada tingkat kesamaan $60 \%$, populasi KA1, AP1, PS2 dan KA2 membentuk dua kelompok dan baru pada tingkat kesamaan $65 \%$ populasi KA1 mengelompok dengan AP1. Sementara populasi PS2 mengelompok dengan populasi KA2 pada tingkat kesamaan $70 \%$.

Kebugaran parasitoid dari populasi geografi berbeda. Parasitoid berasal dari populasi Kayu Aro menunjukkan kebugaran paling baik dibanding Pandai Sikek dan Alahan Panjang (Tabel 1). Jumlah telur, lama hidup dan laju peletakkan telur parasitoid Kayu Aro berbeda nyata $(P=0,00)$ sedangkan untuk telur hari I tidak menunjukkan perbedaan nyata $(\mathrm{P}=0,07)$ antara ketiga populasi. Parasitoid yang berasal dari ketiga tempat menunjukkan perbedaan nyata pada kemampuan parasitisasi dan superparasitisasi $(\mathrm{P}=0,00)$. Parasitoid 
$\begin{array}{llllll}1 & 2 & 3 & 4 & 5 & 6\end{array}$

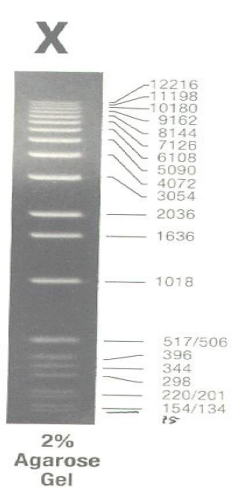

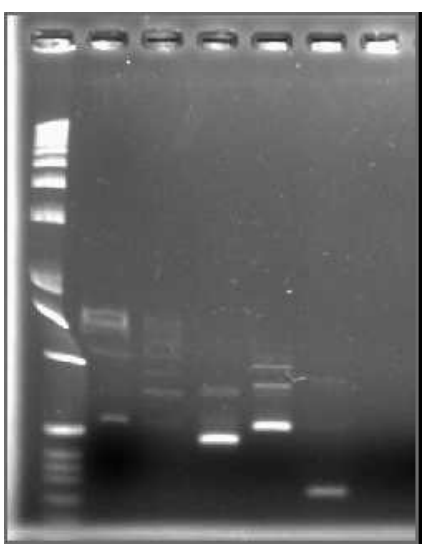

A $\begin{array}{llllll}1 & 2 & 3 & 4 & 5 & 6\end{array}$

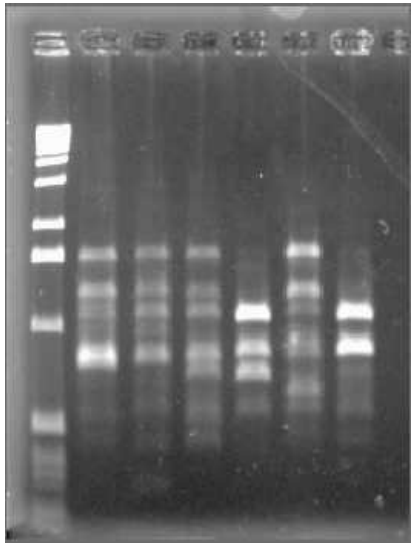

B

Gambar 1. Pola pita hasil amplifikasi enam sampel DNA $H$ varicornis dengan primer OPJ-04; A. dan OPN-16 (5'-AAGCGACCTG-3'); B. Kolom 1 adalah populasi KA1, kolom 2 populasi AP1, kolom 3 populasi AP2, kolom 4 populasi PS1, kolom 5 populasi PS2 dan kolom 6 populasi KA2

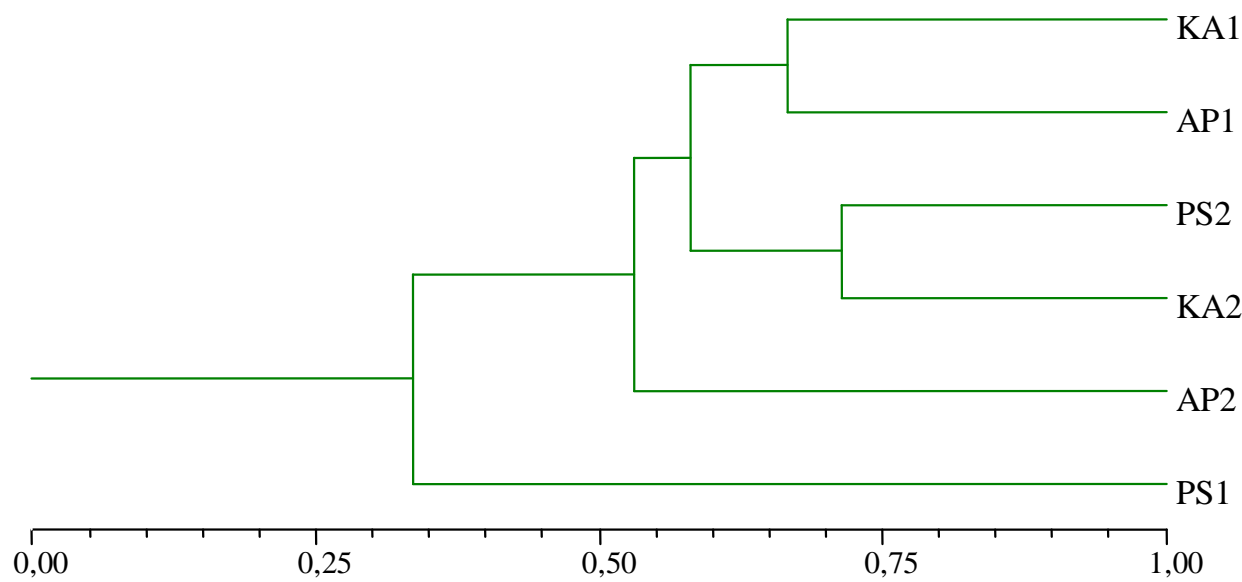

Koefisien Kesamaan Genetik

Gambar 2. Dendogram kesamaan genetik penanda RAPD (primer OPN-16) antar populasi H. varicornis di Sumatera Barat

Tabel 1. Rataan lama hidup, jumlah telur, laju peletakkan telur dan telur hari I betina $H$. varicornis berasal dari ketinggian tempat berbeda

\begin{tabular}{lrcr}
\hline \multirow{2}{*}{ Parameter kebugaran } & \multicolumn{3}{c}{ Daerah Asal } \\
\cline { 2 - 4 } & \multicolumn{1}{c}{ Pandai Sikek } & Alahan Panjang & Kayu Aro \\
\cline { 2 - 4 } & \multicolumn{1}{c}{$\mathrm{x} \pm \mathrm{sd}$} & $\mathrm{x} \pm \mathrm{sd}$ & $\mathrm{x} \pm \mathrm{sd}$ \\
\hline Lama hidup (hari) & $12,10 \pm 7,59 \mathrm{~b}$ & $8,75 \pm 3,10 \mathrm{~b}$ & $24,60 \pm 6,40 \mathrm{a}$ \\
Jumlah telur (butir) & $15,75 \pm 16,6 \mathrm{~b}$ & $8,15 \pm 6,70 \mathrm{~b}$ & $63,60 \pm 28,60 \mathrm{a}$ \\
Laju peletakan telur (butir/hari) & $1,14 \pm 0,46 \mathrm{~b}$ & $0,93 \pm 0,69 \mathrm{~b}$ & $2,49 \pm 0,70 \mathrm{a}$ \\
Jumlah telur hari I (butir) & $0,45 \pm 0,70 \mathrm{a}$ & $0,50 \pm 0,50 \mathrm{a}$ & $1,10 \pm 1,40 \mathrm{a}$ \\
\hline
\end{tabular}

Perbedaan huruf kecil menurut baris, berbeda nyata pada taraf nyata 0,05 dengan uji Tukey $(n=20)$. 
KA memiliki kemampuan parasitisasi dan superparasitisasi tertinggi dibanding Pandai Sikek dan Alahan Panjang (Tabel 2).

Masa praoviposisi yang dimiliki oleh masingmasing parasitoid berbeda. Parasitoid berasal dari KA memiliki masa praoviposisi lebih pendek daripada AP dan PS. Sebanyak $90 \%$ betina KA meletakkan telur pertama sebelum 12 jam sementara sebaliknya $90 \%$ AP dan 70\% PS meletakkan telur pertama lebih dari 12 jam (Gambar 3).

\section{Persilangan H. varicornis dari Populasi Berbeda}

Daerah. Persilangan interpopulasi $H$. varicornis tidak berpengaruh nyata terhadap lama hidup betina $(\mathrm{P}=0,0245)$ dan lama hidup jantan $(\mathrm{P}=0,316)$. Sebaliknya, interpopulasi menunjukkan pengaruh terhadap jumlah telur dan persentase keberhasilan telur menjadi imago $(\mathrm{P}=0,0)$. Jumlah telur dari persilangan $\mathrm{PS} \propto$ x AP $\hat{O}$ memperlihatkan penurunan nyata (dibanding intrapopulasi PSO $\mathrm{x}$ PS ${ }^{\widehat{\lambda}}$, tetapi tidak demikian halnya

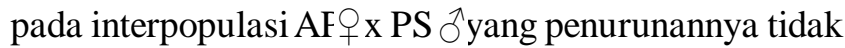
nyata (dibanding dengan intrapopulasi $\mathrm{AP} \propto \times \mathrm{AP} \widehat{\bigcirc}$ (Tabel 3).

Nisbah kelamin anak yang dihasilkan dari setiap kombinasi persilangan menunjukkan perbedaan. Persilangan interpopulasi baik $\mathrm{PS}+\mathrm{x} \mathrm{AP} \widehat{\sigma}$ maupun $\mathrm{AP} \propto$ × $\mathrm{PS} \hat{\jmath}$ menghasilkan jumlah anak betina lebih sedikit dan berbeda nyata $(\mathrm{P}=0,0013$ dan $\mathrm{P}=0,0026)$ dibanding intrapopulasi masing-masingnya $(\mathrm{PS} q \mathrm{x} \mathrm{PS} \delta$ dan $\mathrm{AP}+\mathrm{x} \mathrm{AP} \hat{\jmath})$. Sementara, terhadap anak jantan yang dihasilkan, pada interpopulasi $\mathrm{AP}+\mathrm{x}$ PS ${ }^{\lambda}$ tidak memperlihatkan perbedaan nyata $(\mathrm{P}=$

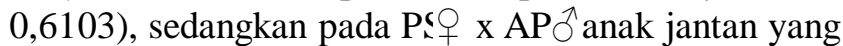
dihasilkan berbeda nyata $(\mathrm{P}=0,0006)$ (Tabel 4). Nilai
RC dari persilangan AP dan PS masing-masing 0,70 dan $0,61 \%$ untuk APO $\times$ PS ${ }^{\lambda}$. Sesuai kategori oleh Pinto et al. (1991) nilai tersebut mengindikasikan inkompatibel pada persilangan populasi AP dan PS.

Keragaman genetik. Populasi $H$. varicornis yang terdistribusi di Pandai Sikek, Alahan Panjang dan Kayu Aro menunjukkan variasi genetik cukup tinggi. Keragaman genetik yang cukup tinggi disebabkan oleh terdapat hambatan geografis terutama jarak yang cukup besar untuk memungkinkan terjadi perpindahan populasi secara alami. Jarak antara Pandai Sikek dan Alahan Panjang kurang lebih $140 \mathrm{~km}$ demikian pula dari Alahan Panjang ke Kayu Aro berjarak lebih kurang 160 km (Gambar 4).

Distribusi parasitoid terbawa dalam perpindahan komoditi melalui jalur perdagangan sangat efektif. Fase telur atau larva parasitoid dapat terbawa bersamaan inang L. huidobrensis dalam liang korokan daun. Hal ini dapat terjadi disebabkan rentang waktu pemarasitan (stadium larva) $H$. varicornis berkisar antara 3 sampai 4 hari sehingga cukup waktu untuk bertahan dan berpindah dalam jarak yang panjang. Rute transportasi perdagangan komoditi sayuran yang selama ini berlangsung adalah dari Kayu Aro melalui Alahan Panjang sampai ke Bukittinggi dan sekitarnya (Pandai Sikek) (Gambar 4). Oleh karena itu sangat memungkinkan terjadi perpindahan populasi dari KA ke AP dan PS sehingga menyebabkan tingkat kesamaan yang cukup besar antara KA2 dan PS2 (70\%) dan KA1 dan AP1 (65\%) (Gambar 2).

Akan tetapi, bagaimana terjadi perbedaan genetik cukup besar pada populasi-populasi dalam satu hamparan lansekap agroekosistim dapat terjadi? Kami

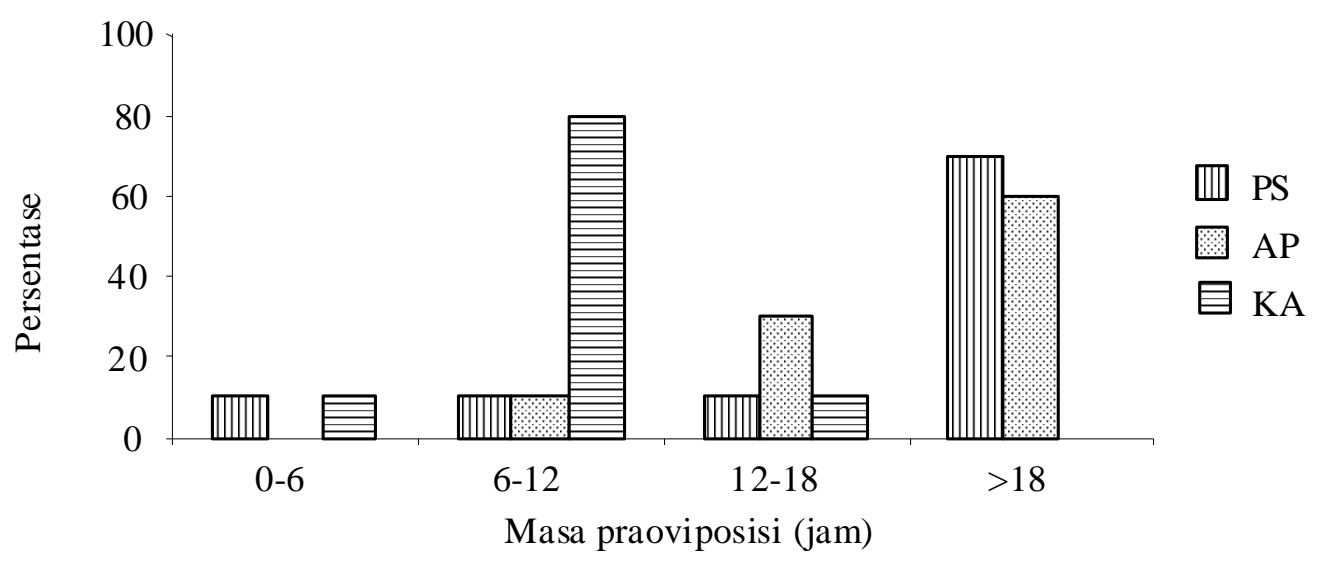

Gambar 3. Masa praoviposisi H.varicornis berasal dari Pandai Sikek (PS), Alahan Panjang (AP) dan Kayu Aro (KA) 
Tabel 2. Kemampuan parasitisasi dan superparasitisasi $H$. varicornis yang berasal dari Pandai Sikek, Alahan Panjang dan Kayu Aro

\begin{tabular}{cccccc}
\hline Daerah asal & $\begin{array}{c}\text { Rataan inang } \\
\text { dipaparkan (ekor) }\end{array}$ & $\begin{array}{c}\text { Rataan inang } \\
\text { diparasit (ekor) }\end{array}$ & $\begin{array}{c}\text { Parasitisasi } \\
(\%)\end{array}$ & $\begin{array}{c}\text { Super parasitisasi } \\
(\text { ekor) }\end{array}$ & $\begin{array}{c}\text { Super parasitisasi } \\
(\%)\end{array}$ \\
\hline KA & 73,8 & 40 & $53,60 \mathrm{a}$ & 14,4 & $19,26 \mathrm{a}$ \\
PS & 36,3 & 11,05 & $29,20 \mathrm{~b}$ & 3,15 & $6,38 \mathrm{~b}$ \\
AP & 26,25 & 6,2 & $23,54 \mathrm{~b}$ & 1,15 & $4,27 \mathrm{~b}$ \\
\hline
\end{tabular}

Perbedaan huruf kecil menurut kolom, berbeda nyata pada taraf nyata 0,05 dengan uji Tukey.

Tabel 3. Lama hidup, jumlah telur dan persentase telur survival dari perkawinan intra dan interpopulasi H. varicornis

\begin{tabular}{|c|c|c|c|c|}
\hline \multirow{2}{*}{ Parameter biologi } & \multicolumn{2}{|c|}{ Intrapopulasi } & \multicolumn{2}{|c|}{ Interpopulasi } \\
\hline & $\mathrm{AP}_{+} \times \mathrm{AP}^{\lambda}$ & $\mathrm{PS} \propto \mathrm{x} \mathrm{PS}{ }^{\lambda}$ & $\mathrm{AP}+\mathrm{xPS} \widehat{\jmath}$ & $\mathrm{PS}+\times \mathrm{AP}^{\lambda}$ \\
\hline $\begin{array}{l}\text { Lama hidup betina } \\
\text { (hari) }\end{array}$ & $24,55 \pm 1,80 \mathrm{a}$ & $30,55 \pm 1,80 \mathrm{a}$ & $22,56 \pm 2,69 a$ & $22,90 \pm 2,55 a$ \\
\hline $\begin{array}{l}\text { Lama hidup jantan } \\
\text { (hari) }\end{array}$ & $18,35 \pm 3,67 \mathrm{a}$ & $21,05 \pm 5,62 \mathrm{a}$ & $19,30 \pm 3,16 a$ & $19,50 \pm 4,74 \mathrm{a}$ \\
\hline $\begin{array}{l}\text { Jumlah telur/betina } \\
\text { (butir) }\end{array}$ & $18,00 \pm 2,69 \mathrm{~b}$ & $37,85 \pm 18,59 a$ & $10,40 \pm 2,17 \mathrm{~b}$ & $8,30 \pm 2,21 b$ \\
\hline Telur jadi imago (\%) & $66,00 \pm 3,64 \mathrm{a}$ & $40,98 \pm 3,64 b$ & $71,33 \pm 5,43 a$ & $68,30 \pm 5,15 a$ \\
\hline
\end{tabular}

Angka-angka dalam baris yang sama yang diikuti oleh huruf yang sama dibelakangnya menunjukkan perbedaan tidak nyata dengan menggunakan Uji Tukey pada taraf nyata $\alpha=0,05$.

Tabel 4. Perbandingan jumlah anak jantan dan betina dan nilai RC hasil persilangan $H$. varicornis geografi berbeda

\begin{tabular}{|c|c|c|c|c|c|c|}
\hline \multirow{2}{*}{ Kombinasi perkawinan } & \multirow{2}{*}{$\mathrm{n}$} & \multicolumn{2}{|c|}{ Jumlah anak } & \multirow{2}{*}{$\mathrm{MSR}^{2}$} & \multirow{2}{*}{\multicolumn{2}{|c|}{ Keterangan }} \\
\hline & & $\hat{0}$ & q & & & \\
\hline (intrapopulasi) $\mathrm{AP} \propto$ x $\mathrm{AP} \widehat{\ominus}$ & 20 & $5,00 \pm 0,45 \mathrm{a}^{1}$ & $6,4 \pm 3,30 a^{1}$ & 0,56 & & \\
\hline (interpopulasi)AP $\odot$ x PS $\curvearrowright$ & 10 & $4,60 \pm 0,64 \mathrm{a}^{1}$ & $2,9 \pm 0,57 \mathrm{~b}^{1}$ & 0,39 & $0,70^{4}$ & Inkompatibel \\
\hline (intrapopulasi)PS $\propto$ x $\mathrm{PS} \curvearrowright$ & 20 & $6,90 \pm 0,45 x^{1}$ & $7,3 \pm 4,88 x^{1}$ & 0,51 & & \\
\hline (interpopulasi) $\mathrm{PS} q$ x $\mathrm{AP} \widehat{\jmath}$ & 10 & $3,80 \pm 0,64 y^{1}$ & $1,7 \pm 0,95 \mathrm{y}^{1}$ & 0,31 & $0,61^{4}$ & Inkompatibel \\
\hline
\end{tabular}

1 Perbandingan jenis kelamin anak dari masing-masing persilangan intrapopulasi dan interpopulasi menggunakan UjiTukey $(\alpha=0,05)$.

${ }^{2}$ MSR (mean sex ratio) adalah proporsi anak betina dalam satu generasi keturunan.

${ }^{3} \mathrm{RC}$ (reproductive compatibility) adalah perbandingan MSR interpopulasi dengan intrapopulasi (Liu et al., 2002).

${ }^{4}$ Nilai RC<75\% menunjukan inkompatibel (Pinto et al., 1991). 


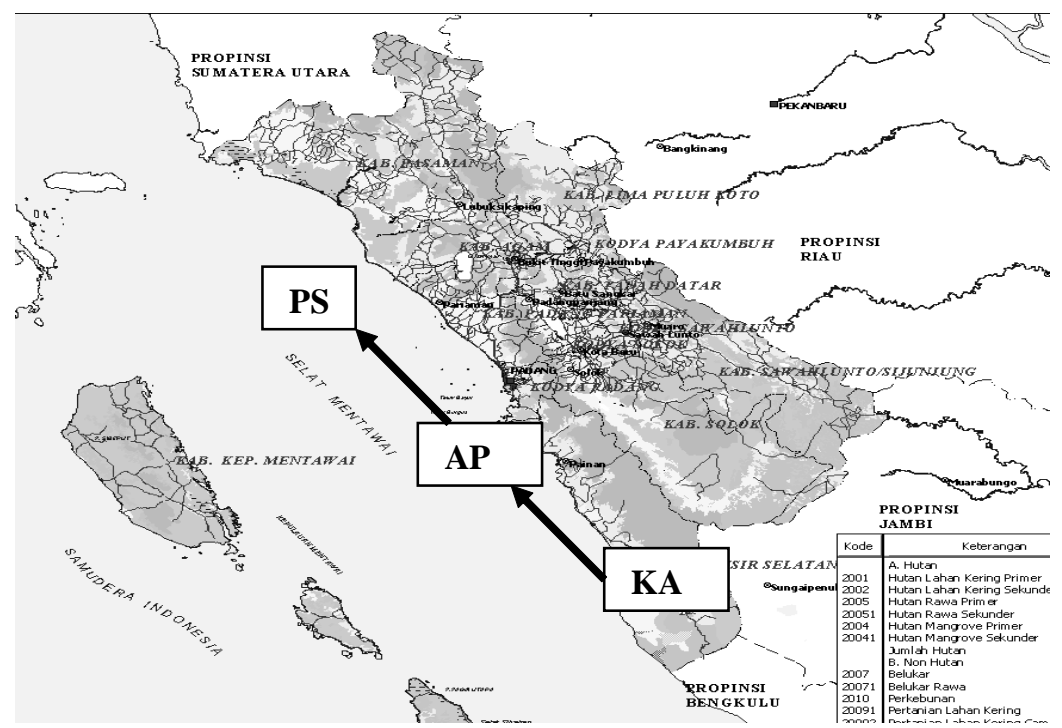

Gambar 4. Pola penyebaran potensial $H$. varicornis mengikuti jalur transportasi tanaman inang (tanda panah)

menduga keragaman intraspesifik intrapopulasi yang tinggi pada populasi PS1 dan PS2, KA1 dan KA2 serta AP1 dan AP2 disebabkan oleh hambatan akibat adanya fragmentasi habitat dan kemampuan terbang parasitoid yang terbatas. Fragmentasi habitat dapat berupa tanaman non inang yang ditemukan menyusun struktur vegetasi agroekosistem. Di Alahan Panjang dan Kayu Aro tanaman inang yang dominan adalah kentang sedangkan di Pandai Sikek tanaman buncis. Berbeda dengan di Alahan Panjang dan Kayu Aro dimana tanaman kentang dengan areal yang cukup luas, di Pandai Sikek buncis hanya ditanam dalam areal sangat kecil dan adakalanya hanya sebagai tanaman selingan. Disamping itu, struktur vegetasi di Pandai Sikek lebih didominasi oleh tanaman padi yang bukan tanaman inang Liriomyza sehingga menyebabkan hambatan yang selalu ditemukan. Dengan demikian, adanya fragmentasi habitat menyebabkan populasi satu dengan lainnya menjadi terpisah sehingga tidak memungkinkan terjadi aliran gen (gen flow).

Faktor lain penyebab tingginya keragaman parasitoid dalam satu daerah adalah keterbatasan kemampuan terbang imago. Hal ini diduga kuat sebagai penyebab tingkat ketidaksamaan populasi dalam satu daerah menjadi rendah (PS1 dan PS2 <35\%, AP1 dan AP2 $<55 \%$, KA1 dan KA2 <60\%). Keterbatasan penerbangan akan menjadi lebih tinggi bila ditemukan halangan (barrier) yang berupa tanaman non inang dalam ekosistem. Oleh karena itu diperlukan kajian terhadap kemampuan terbang imago yang akan menjelaskan hal ini lebih mendalam.
Kebugaran parasitoid. Parasitoid berasal dari Kayu Aro memperlihatkan kebugaran paling baik diantara ketiga populasi. Kemampuan meletakkan telur ternyata sangat ditentukan masa hidup betina. Hal serupa diperlihatkan pula pada parasitoid yang berasal dari beberapa daerah di Jawa. Betina berasal dari Pangalengan dengan lama hidup lebih panjang memiliki keperidian tertinggi dibanding betina berasal Banjarnegara, Garut dan Wonosobo (Reflinaldon et al., 2000). Kemampuan meletakkan telur sepanjang hidup betina merupakan salah satu karakter parasitoid synovigenik seperti pada H.varicornis. Masa pematangan telur dapat berlangsung selama hidup betina. Oleh karena itu, kebutuhan sumber nutrisi bagi betina mutlak dibutuhkan dalam pematangan telur (Hidrayani, 2005).

Masa praoviposisi yang lebih cepat pada KA (Gambar 1) ternyata tidak memiliki kaitan dengan peletakkan telur hari pertama. Praoviposisi cenderung memerlukan masa lebih lama pada synovigenik sehingga berkaitan dengan perilaku dewasa imago untuk mencari pakan sebelum menemukan inang.

Inkompatibilitas. Persilangan interpopulasi APbxPSj dan PSbxAPj menunjukkan inkompatibilitas karena proporsi anak betina yang dihasilkan menjadi lebih sedikit. Kejadian ini dapat disebabkan oleh meningkatnya telur yang tidak difertilisasi sehingga menghasilkan kelamin jantan. Pada sistem reproduksi arenotoki, telur yang dibuahi (fertilized egg) berkembang menjadi jantan (Godfray, 1994). Penjelasan lainnya, telur-telur yang 
telah dibuahi gagal berkembang menjadi betina karena mengalami kematian sebelum matang. Dalam percobaan ini terlihat tingkat keberhasilan telur menjadi imago hanya sekitar $70 \%$ pada persilangan interpopulasi (Tabel 2). Hal yang sama ditemukan pada inkompatibilitas antar strain Trichogramma deion Stouthamer et al. (2000). Pada beberapa kasus dilaporkan bahwa ditemukan adanya isolasi reproduksi yang bersifat postzygotyc oleh jenis bakteri sitoplasmik yaitu Wolbachia pada parasitoid Nasonia yang disilangkan dari berbagai populasi sehingga menghasilkan keturunan yang bias jantan (Bordenstein et al., 2000).

\section{SIMPULAN}

Keragaman $H$. varicornis dari berbagai tempat pertanaman sayuran di Sumatera Barat ternyata cukup tinggi terlihat dari karakter molekuler dan sifat kebugarannya. Parasitoid yang berasal dari populasi Kayu Aro memiliki potensi reproduksi paling baik dibanding populasi parasitoid dari Pandai Sikek dan Alahan Panjang. Persilangan antar populasi H.varicornis dari Alahan Panjang dan Pandai Sikek mengindikasikan ketidaksesuaian reproduksi.

\section{SANWACANA}

Terima kasih disampaikan kepada DP3M Direktorat Jendral Pendidikan Tinggi yang mendanai sebagian penelitian melalui Program Penelitian Hibah Bersaing XV tahun 2003-2005. Ucapan terima kasih dan penghargaan juga disampaikan kepada Sdr. Reflinur, Damanhuri, Astridawati dan Sugiartati yang membantu dalam pengumpulan data di lapang dan laboratorium.

\section{DAFTAR PUSTAKA}

Bordenstein SR, Drapeau MD \& Werren JH. 2000. Intraspesific variation in sexual isolation in jewel wasp Nasonia. Evolution 54(2): 567-573.

Diehl SR \& GL Bush. 1984. An evolutionary and applied perspective of insect biotypes. Annu. Rev. Entomol. 29: 471-483.

Godfray HCJ. 1994. Parasitoid behavioural and evolutionary biology. Princeton Univ. Press. Chichester.UK.

Hidayat P. 2000. Aplikasi teknik RAPD-PCR untuk studi parasitoid. Makalah dalam Pelatihan Parasitoid
Pusat Kajian Pengendalian Hama Terpadu, 2-25 Februari 2000.

Hidrayani. 2005. Hemiptarsenus varicornis (Girault) (Hymenoptera: Eulophidae), parasitoid Liriomyza huidobrensis (Blanchard) (Diptera: Agromyzidae): bioekologi dan parasitisasi. Disertasi. Bogor, Institut Pertanian Bogor.

Hoy MA. 1994. Insect Moleculer Genetics, An Introduction to Principles and Applications. Academic Press.

Liu, Shu-sheng, Gebremeskel FB \& Shi, Zu-hua. 2002. Reproductive compatibility and variation in survival and sex ratio between two geographic populations of Diadromus collaris, a pupal parasitoi of the diamond back moth, Plutella xylostella. Biocontrol 47: 625-643.

Loxdale HD, Brookes CP \& De Barro PJ. 1996. Application of novel moleculer markers (DNA) in agricultural entomology Pp. 150-198 In: Symondson WOC \& Liddell JE, eds. The Ecology of Agricultural Pests. Chapman and Hall.

Mackenzie A, Ball AS \& Virdee SR. 1998. Instant Notes in Ecology. Bios Scientific Pub. Ltd. Oxford.

Meilin A. 1999. Keragaman karakter morfologi dan genetik populasi parasitoid telur, Trichogramma spp. dan Trichogrammatoidea spp. (Hymeneoptera: Trichogrammatidae) dari daerah geografis berbeda di Pulau Jawa. Tesis Program Pascasarjana, IPB.

Purnomo, Rauf A, Sosromarsono S \& Santoso T. 2003 Parasitoid lalat pengorok daun pada pertanaman kentang dan tumbuhan liar di wilayah Pangalengan. Makalah Kongres PEI dan Simposium Entomologi VI, 5-7 Maret 2003.

Pinto JD, Stouthamer R, Platner GR \& Oatman ER. 1991. Variation in reproductive compatibility in Trichogramma and its taxonomic significance (Hymenoptera: Trichogrammatidae). Ann. Entomol. Soc. Am. 84: 37-46. 
Rauf A. 2003. Pengembaraan hama invasif Liriomyza spp. pada peralihan dan awal milenium II: respon petani dan musuh alami di Indonesia. Makalah Kongres PEI dan Simposium Entomologi VI, 5-7 Maret 2003.

Rauf A\& Shepard BM. 1999. Leafminers in vegetables in Indonesia: Survey of host crops, species composition, parasitoids and control practices. Paper presented in Workshop on leafminers of vegetables in Southeast Asia. Malaysia, CAB Int. 2-5 February 1999.

Reflinaldon, Rauf A \& Novizar. 1999. Liriomyza huidobrensis (Diptera: Agromyzidae): Tantangan petani di dataran tinggi Sumatera Barat. $J$. Manggaro 1(2): 49-52.
Reflinaldon, Yaherwandi, Hidrayani \& Damayanthi B. 2000. Fragmentasi habitat dan keragaman parasitoid Liriomyza huidobrensis (Blanchard) (Diptera: Agromyzidae) pada berbagai struktur lansekap. Laporan Penelitian Domestic Collaboration Research Grant (DCRG). Urge Project.

Sembel DT, Kandawangko DS \& Watung J. 2003. Survey on Liriomyza spp. (Diptera: Agromyzidae) and their parasitoids in North Sulawesi. Makalah Kongres PEI dan Simposium Entomologi VI, 5-7 Maret 2003.

Stouthamer R, Jochemsen P, Platner GR \& Pinto JD. 2000. Crossing incompatibility between Trichogramma minutum and $T$. platneri (Hymenoptera: Trichogrammatidae): Implication for application in biological control. Environ. Entomol. 29(4): 832-837. 